\title{
Biocontrol of the banana root borer weevil, Cosmopolites sordidus (Germar), with Steinernematid nematodes ${ }^{\top}$
}

\author{
Wilfredo Figueroa ${ }^{2}$
}

\begin{abstract}
The entomogenous nematodes Steinernema feltiae Filipjev ( = Neoaplectana carpocapsae Weiser), S. glaseri Steiner, and S. bibionis Bobien (Steinernematidae: Rhabditida) were evaluated as biological control agents against the banana root borer weevil Cosmopolites sordidus. In the grub stage this weevil bore tunnels in the corms of plantains thereby promoting infection and plant decay. In petri-dish trials the three species produced severe mortality at population densities of 4,000 and 40,000 nematodes. Similarly, in greenhouse tests, the three nematode species at rates of $400,4,000$, and 40,000 nematodes/4-month-old plants apparently reduced the number of tunnels produced by the grub. Grub mortality was $100 \%$ at nematode populations of 4,000 and 40,000 per plant.
\end{abstract}

\section{RESUMEN}

Control biológico del gorgojo del platanero, Cosmopolites sordidus, con nematodos esteinernematidos

Se evaluaron los nematodos entomofilitos Steinerma feltiae, S. glaseri y $S$. bibionis como agentes de control biológico para el gorgojo del plátano y el guineo, Cosmopolites sordidus. Durante la etapa larval este insecto hace túneles en el rizoma de los plataneros, lo que posibilita el desarrollo de la infección y pudrición del cormo. En pruebas de laboratorio las tres especies de nematodos causaron mortalidad severa de las larvas del gorgojo cuando se aplicaron en densidades de 4,000 y 40,000 nematodos. De igual manera, en pruebas de invernadero las tres especies de nematodos en densidades de $400,4,000$ y 40,000 nematodos por planta de plátano aparentemente causaron una disminución en el número de túneles por planta. La mortalidad de las larvas ascendió a $100 \%$. En este experimento se demostró la efectividad de los nematodos entomofílicos para controlar las larvas del gorgojo del plátano y su potencial como agente de control biológico.

\section{INTRODUCTION}

Plantains and bananas are important starchy food crops in Puerto Rico, the Virgin Islands and the Caribbean basin. In 1987-88 their value attained $\$ 38.4$ million in Puerto Rico. There are over 12,000 acres under cultivation (2). The crop acreage is expanding with consumer demand.

A major pest that adversely affects plaintain and banana production is the root borer weevil, Cosmopolites sordidus. The larvae bore tunnels

${ }^{1}$ Manuscript submitted to Editorial Board 18 October 1988.

${ }^{2}$ Assistant Nematologist, Department of Crop Protection. 
in the corm, thereby producing severe damage. The affected corm becomes susceptible to fungal and bacterial attacks that reduce it to a dark mass of decaying tissue $(12,14)$. As a consequence the plant shows a permanent decay and poor yield, which almost never allows a healthy growth of suckers; a vigorous first ratoon is seldom, if ever, attainable. Losses of plantain and banana are thought to approach $50 \%$ when the weevil is not controlled (3).

Because of the cryptic habits of $C$. sordidus, most of the commercial insecticides are not effective against the insect's grub stage. A possible means to control this insect is the use of entomogenous nematodes of the genus Steinemema. These bacterium-associated nematodes can destroy a wide range of soil-borne, and stem-boring insects which attack various agricultural crops. Their effectivity has been reported from numerous sources $(1,8,9,11)$. This spectrum of activity is more characteristic of a chemical than a biological insecticide (5). Intensive research has demonstrated that these nematodes lack mammalian, bird and plant pathogenicity and the US Environmental Protection Agency has subsequently exempted steinernematids and heterorhabditis from registration requirements $(4,7)$. Current research might enable insect killing nematodes to be economically competitive with many insecticides (6). Laumond, Mauleon, and Kermarrec (10) in laboratory trials showed that adult weevils of $C$. sordidus were very susceptible to Neoaplectana carpocapsae.

A review of the literature shows no other work realized with this insect and entomopathogenic nematodes in the Caribbean Basin.

Strictly, the objectives of the present work are to investigate the possibility of utilizing the nematodes Steinernema (= Neoaplectana) feltiae, $S$. glaseri and $S$. bibionis for the control of the borer weevil $C$. sordidus.

\section{MATERIALS AND METHODS}

Two experiments were conducted to test the efficacy of $S$. feltiae, $S$. glaseri and $S$. bibionis against larvae of $C$. sordidus. Nematode species were obtained from Biosys, Inc. The first trial was performed under laboratory conditions. Mature banana borer larvae, about 11 to $12 \mathrm{~mm}$ long, approximately 6 and 7 instars were collected from infested live plants and brought to the laboratory inside healthy corms. Four larvae were introduced into two corm discs $5 \times 7 \times 7 \mathrm{~cm}$ which were placed in a 14-cm diameter petri dish lined with filter paper. Each of the three species was administered at population rates of 4,000 and 40,000 infective juveniles. These were contained in $5 \mathrm{ml}$ of distilled water poured evenly over the two corm discs. Other corm discs received $5 \mathrm{ml}$ of water as the control treatment. Each treatment was replicated 5 times in a randomized block design. Grub mortality was recorded 4 days after treatment. 
In the second test, healthy plantain suckers were planted in $18.9 \mathrm{~L}$ plastic pots filled with steam sterilized soil. Plants were maintained in the greenhouse for 4 months to allow for a strong healthy rhizome. Two $3 \mathrm{~mm}$ holes were bored with a cork borer in each rhizome to provide immediate access and the humidity required for larval survival. One 11to $12-\mathrm{mm}$ long larva was introduced at each boring. After 24 hours, plants received each of the three nematode species at $400,4,000$ or 40,000 infective nematodes administered in $20 \mathrm{ml}$ of water poured around the rhizome. Other plants receiving $20 \mathrm{ml}$ of water served as a control. Each treatment was replicated 4 times in a randomized block design. Temperature during the course of the experiment ranged from $20^{\circ} \mathrm{C}$ to $31^{\circ} \mathrm{C}$. Soil humidity was maintained at approximately 50 to $60 \%$ field capacity. Each plant was fertilized monthly with a 20-20-20 fertilizer water solution. Grub mortality was recorded 12 days after nematode inoculation. Additionally, the number of tunnels produced by the grubs themselves was estimated by using a corm damage rating of 0 to 4 (table 1). These observations were performed in accordance with Vilardebo (13). All data were submitted to statistical analysis of variance, and mean values were evaluated by Duncan's multiple range test.

\section{RESULTS}

In the laboratory trials nematode treatment of $S$. feltiae at 4,000 density and S. glaseri and $S$. bibionis at 4,000 and 40,000 nematodes/petri dish were effective against the grubs when compared with the control. $S$. glaseri and $S$. bibionis were more consistent than $S$. feltiae as both species provided equal mortality at the two densities (table 2).

Grub mortality under greenhouse conditions was severe regardless of the density and nematode species employed (table 3 ). All nematode treatments rendered a minimal $75 \%$ grub mortality, significantly superior to that of the control. For the three densities used each of the three nematode species was capable of reducing sigificantly the number of tunnels caused by the grubs (table 4 ).

TABLE 1.-Damage rating scale and correponding corm injury by the banana root borer weevil, as applied by Vilardebo (13)

\begin{tabular}{clc}
\hline Rating & Plant condition & Vilardebo's rating \\
\hline 0 & No damage & 0 \\
1 & $25 \%$ tissue damage & 20 \\
2 & $50 \%$ tissue damage & 40 \\
3 & $75 \%$ tissue damage & 60 \\
4 & $100 \%$ tissue damage & 100 \\
\hline
\end{tabular}


TABI E 2.-. Mortality of larvae of Cosmopolites sordidus exposed to three species of steinernematid nematodes under laboratory conditions

\begin{tabular}{lcc}
\hline Nematode specie & Number per treatment & Grub mortality (\%) \\
\hline S. feltice & 4,000 & $53.0 \mathrm{a}$ \\
& 40,000 & $13.0 \mathrm{bc}$ \\
S.glaseri & 4,000 & $60.0 \mathrm{a}$ \\
& 40,000 & $60.0 \mathrm{a}$ \\
S. bibionis & 4,000 & $66.0 \mathrm{a}$ \\
& 40,000 & $40.0 \mathrm{ab}$ \\
Control & 0 & $0.0 \mathrm{c}$ \\
\hline
\end{tabular}

'Values in columns followed by a common letter do not differ significantly at $\mathrm{P}=0.05$ according to Duncan's multiple range test.

TABLE 3.-Mortality of Cosmopolites sordidus grubs in infested plantains following treatment with three species of steinernematid nematodes

\begin{tabular}{crrr}
\hline & \multicolumn{3}{c}{ Grub\% mortality produced by species } \\
\cline { 2 - 4 } (Nematodes/plant) & S. felliae & S. glaseri & S. bibionis \\
\hline 400 & $88.0 \mathrm{a}^{\mathrm{i}}$ & $100.0 \mathrm{a}$ & $75.0 \mathrm{a}$ \\
4,000 & $100.0 \mathrm{a}$ & $100.0 \mathrm{a}$ & $100.0 \mathrm{a}$ \\
40,000 & $100.0 \mathrm{a}$ & $100.0 \mathrm{a}$ & $100.0 \mathrm{a}$ \\
0 (Control) & $25.0 \mathrm{~b}$ & $25.0 \mathrm{~b}$ & $25.0 \mathrm{~b}$ \\
\hline
\end{tabular}

1 Values in columns followed by a common letter do not differ significantly at $P=0.05$ according to Duncan's multiple range test.

\section{DISCUSSION AND CONCLUSIONS}

Results from this study suggest that the nematodes of the three Steinemema species can control the 6-to 7-instar larvae of $C$. sordidus causing in some instances over $50 \%$ mortality, which for this insect seems to be acceptable in terms of the difficulty of its control. The nematodes assisted by the sheltered environment of the corm obviously found the appropriate humidity for survival and movement necessary to search out and kill the insect grubs within the tunnels. Corm damage was apparently reduced by the nematode action (tables 3 and 4 ). This experiment indicated that the 6-to 7-instar larvae of this weevil were very vulnerable to the three nematode species when used at population densities of 400 to 40,000 per plant. Thus steinernematid nematodes can be agents of biological control. Field trials should be performed to investigate the effectiveness of these nematodes against many tropical soil-inhabiting and stem-boring insects which at present are difficult to control with existing chemicals. 
TABLE 4.-Effectiveness of three steinermematid nematode species in reducing the tunnelboring activity of $\mathrm{C}$. sordidus in plantain

\begin{tabular}{cccr}
\hline & \multicolumn{3}{c}{ Number of corm horings per treatment' } \\
\cline { 2 - 4 } Treatment \\
(nematodes/plant) & S. feltiae & S.glaser & S. bitionis \\
\hline 400 & $1.50 \mathrm{a}^{2}$ & $1.00 \mathrm{a}$ & $1.25 \mathrm{a}$ \\
4,000 & $1.00 \mathrm{a}$ & $1.00 \mathrm{a}$ & $1.00 \mathrm{a}$ \\
40,000 & $1.00 \mathrm{a}$ & $1.00 \mathrm{a}$ & $1.00 \mathrm{a}$ \\
0 (Control) & $3.25 \mathrm{~b}$ & $3.25 \mathrm{~b}$ & $3.25 \mathrm{~b}$ \\
\hline
\end{tabular}

'Based on scale of 0 to 4 , in accordance with Vilardebo (13) in which $0=$ minimal damage and $4=$ maximum damage.

${ }^{2}$ Values in columns followed by a common letter do not differ significantly at $P=0.05$ according to Duncan's multiple range test.

\section{LITERATURE CITED}

1. Bedding, R. A. and A. L. Miller, 1981. Disinfecting black currant euttings of Synanthedon tipnliformis using the insect parasitic nematode, Neoctplectana bibionis. Environ. Entomol. 10: 449-53.

2. Department of Agriculture, 1988. Office of Agricultural Statistics, Commonwealth of Puerto Rico (preliminary figures).

3. Estación Experimental Agrícola, Univ. P. R., 1970. Estimado de la pérdida en la producción de algunas empresas agricolas si se dejaran de combatir los insectos, nematodos y hongos mediante el uso de compuestos químicos.

4. Gaugler, R. and G. M. Boush, 1979. Nonsusceptibility of rats to the entomogenous nematode, Neoaplectano, carpocapsae. Environ. Entomol. 8: 658-60.

5. - 1988. Ecological considerations in the biological control of soil-inhabiting insects with entomopathogenic nematodes. Agric. Ecosys. Environ. 24: 351-60.

6. Georgis, R., 1987. Nematodes for biological control of urban insects. Division of Environmental Chemistry of the American Chemical Society Meeting, 30 August-4 September, New Orleans.

7. Gorsuch, A. M., 1982. Regulations for the enforcement of the Federal Insecticide, Fungicide and Rodenticide Act exemption from regulation of certain biological control agents. Fed. Regist., 47: 23928-3930.

8. Kaya, H. K. and J. E. Lindegren, 1983. Parasitic nematode controls of the western poplar clearwing moth. Calif. Agric. 37: 31-2.

9. - J. L. Joss, L. A. Falcon and A. Berlowitz, 1984. Suppression of the Codling Moth (Lepidoptera:Olethreutidae) with the entomogenous nematode Steinernema feltiae. (Rhabditida:Steinernematidae). J. Econ. Entomol. 77: 1240.

10. Laumond, C., H. Mauleon and A. Kermarrec, 1979. Données sur le spectre d'hôtes et le parasitisme. du nématode entomophage Neocplectana carpocapsae. Entomophaga, 24 (1): 13-27.

11. Lindegren, J. E., T. T. Yamashita and W. W. Bernett, 1981. Parasitic nematode may control carpenter worm in fig trees. Colo. Agric. 35: 25-7.

12. Sein, F., Jr., 1923. El gorgojo del ñame del guineo. Puerto Rico Ins. Exp. Stn., Río Piedras, Circ. 82: 1-7.

13. Vilardebo, A., 1964. How to assess banana weevil borer infestation. Papers Banan. Demon. Four. Guadeloupe. Carib. Ban. Ind. Res. Org., Hato Rey, P. R.

14. Wolcott, G. N., 1948. The Insects of Puerto Rico. J. Agric. Univ. P. R. $32(1,4): 1-975$. 